Journal for Educational Research Online

Journal für Bildungsforschung Online

https://doi.org/10.31244/jero.2021.01.05

Volume 13 (2021), No. 1, 128-156

CC BY-NC-SA 4.0 Waxmann 2021

Cornelia Kristen \& Julian Seuring

\title{
Destination-language acquisition of recently arrived immigrants: Do refugees differ from other immigrants?
}

\begin{abstract}
This article describes new immigrants' levels of destination-language proficiency shortly after taking up residence in Germany. The focus lies on a comparison of refugees from Syria with new arrivals from Italy, Poland, and Turkey, who came as economic immigrants, for family reasons, or as students. The theoretical account builds upon a well-established model of language acquisition, according to which language fluency is a function of exposure, efficiency, and incentives. The empirical study is based on data from the first wave of the ENTRA project ("Recent Immigration Processes and Early Integration Trajectories in Germany") that covers about 4,6oo young adults. The analyses reveal that most individuals improve their proficiency over time. Syrians' experience a faster learning curve than those of other immigrant groups. The conditions identified as relevant to language fluency largely reflect the findings of previous studies. They indicate that language learning is a general process that, for the most part, does not differ across the four groups. Exposure is the major force driving language acquisition. There are also indications that certain kinds of exposure, such as attending language classes, are especially beneficial for individuals with lower resource endowments. In addition, Syrian refugees profit more than other new arrivals from increased levels of language exposure, such as from taking language courses, pursuing education or being active on the labor market.
\end{abstract}

\section{Keywords}

New immigrants; refugees; language proficiency; Germany

Prof. Dr. Cornelia Kristen (corresponding author) · Julian Seuring, University of Bamberg, Feldkirchenstr. 21, 96052 Bamberg, Germany

e-mail: cornelia.kristen@uni-bamberg.de julian.seuring@uni-bamberg.de 


\section{Spracherwerb von Neuzuwanderern: Unterscheiden sich Geflüchtete von anderen Migranten?}

\section{Zusammenfassung}

Im vorliegenden Beitrag werden Muster des Spracherwerbs von Neuzuwanderern beschrieben, welche in jüngerer Zeit nach Deutschland gekommen sind. Der Schwerpunkt liegt auf dem Vergleich syrischer Geflüchteter mit Migranten aus Italien, Polen und der Türkei, die als Arbeitsmigranten, im Zuge der Familienzusammenführung oder für Bildungszwecke eingewandert sind. Die theoretischen Überlegungen beruhen auf einem allgemeinen Modell des Spracherwerbs, wonach drei zentrale Konstrukte beim Erlernen einer Sprache relevant sind: Exposure, Effizienz und Motivation (bzw. Anreize). Für die empirische Studie werden Daten des ENTRA Projekts herangezogen („Aktuelle europäische Binnen- und Flüchtlingsmigration nach Deutschland: Zuzugsprozesse und frühe Integrationsverläufe"), im Rahmen dessen Informationen zu etwa 4,6oo jungen Erwachsenen gesammelt wurden. Die Analysen belegen, dass die meisten Neuzuwanderer ihre Sprachkenntnisse im Zeitverlauf verbessern. Der Zuwachs unter syrischen Geflüchteten fällt dabei deutlicher als in den anderen Gruppen aus. Die für den Spracherwerb gegenwärtiger Neuzuwanderer gefundenen Zusammenhänge entsprechen in weiten Teilen den Befunden früherer Studien. Es wird geschlussfolgert, dass es sich beim Spracherwerb um ein allgemeines Phänomen handelt, das sich in unterschiedlichen Gruppen in ähnlicher Weise vollzieht. Die Schlüsselrolle beim Spracherwerb spielen die Sprachgelegenheiten. Außerdem zeigt sich, dass bestimmte Arten von Exposure, etwa der Besuch von Sprachkursen, für Personen, welche ansonsten über weniger Ressourcen verfügen, besonders vorteilhaft sind. Die Befunde belegen darüber hinaus, dass syrische Geflüchtete in stärkerem Maße als Neuzuwanderer aus anderen Gruppen von Sprachgelegenheiten profitieren, die sich aus der Teilnahme an Sprachkursen, aus dem Besuch von Bildungseinrichtungen oder aus einer Tätigkeit auf dem Arbeitsmarkt ergeben.

\section{Schlagworte}

Neuzuwanderer; Geflüchtete; Spracherwerb; Deutschland

\section{Introduction}

A large body of empirical evidence points to proficiency in the language of the destination country ${ }^{1}$ as central to immigrants' incorporation into their host society. Skills in the dominant language are essential for making and maintaining contacts

1 Throughout this study, we use the terms "language skills" and "language proficiency" interchangeably. In so doing, we intend to cover a broad range of language-related competences without referring to a particular domain (Kristen, Mühlau, \& Schacht, 2016, p. 204). 
with majority members, and thus for establishing social relationships across ethnic boundaries (Martinovic, van Tubergen, \& Maas, 2009; Schacht, Kristen, \& Tucci, 2014). They are also key to immigrants' and their offspring's success in the education system and the labor market. For instance, language skills are required for learning that takes place in the destination country's educational institutions, and thereby shape individuals' achievements (Alba, Sloan, \& Sperling, 2011; Azzolini, Schnell, \& Palmer, 2012; Schnepf, 2007); they are also needed when searching for adequate employment and generating income (Chiswick \& Miller, 1995; Dustmann \& Fabbri, 2003). In structural terms, as well as in many other ways, destination-language proficiency is fundamental to navigating everyday life and to succeeding in a society that can be profoundly different from the one left behind.

In this article, we aim to describe the levels of German-language proficiency that different groups of recently arrived immigrants display shortly after taking up residence in Germany. These skills are indicative of their future integration prospects. Our main focus lies on the comparison of refugees from Syria with new arrivals from Italy, Poland and Turkey, who came as economic immigrants, for family reasons or as students. Given that Syrian refugees left their home country in a time of war and violent conflict, they differ in certain respects from immigrants who came to Germany for other reasons and under different circumstances. For example, refugees are more likely to have experienced a dangerous journey to Europe, and they usually have a different legal status after immigration (Spörlein, Kristen, Schmidt, \& Welker, 2020).

The theoretical account builds upon a general model of language learning, according to which language skills are a function of the efficiency with which immigrants learn a new language, the incentives for investing in its acquisition (i.e., the motivation to learn), and the degree of exposure to this language (Chiswick \& Miller, 1995; 2001). We argue that the basic processes associated with the three constructs of the model apply rather generally to the different immigrant groups under study. That means that new immigrants are expected to respond to most conditions in similar ways, no matter of their origin, or their motive for migrating. Differential patterns may nevertheless emerge, because the groups under study are likely to differ on a range of these conditions. Therefore, rather than reasoning that the processes of language learning have to be addressed in a profoundly different or new way in the case of refugees, we follow arguments which consider refugee migration as a special case of migration that is subject to similar regularities (Kogan \& Kalter, 2020).

This empirical study is based on data from the first wave of the ENTRA project ("Recent Immigration Processes and Early Integration Trajectories in Germany"). The data were collected in 2019 and cover about 4,60o young adults (aged 18 to 41 years) from Syria, Italy, Poland, and Turkey who came to Germany between July 2015 and February 2019.

Unlike other existing data collections that exclusively focus on refugees, the ENTRA survey includes a range of other immigrant populations who came to Germany during a similar period. Poles were selected as a typical case for Eastern 
European immigration; Italians as an example for immigration from Southern Europe, which increased substantially in the aftermath of the financial crises; and Turkish people have been included as an immigrant group that has frequently been considered to be difficult to integrate (Crul \& Vermeulen, 2003), and which, due to being composed mainly of Muslims, faces bright boundaries in the European context (Alba, 2005).

\section{Theoretical account}

Language proficiency is a form of human capital that is embodied in a person (Chiswick \& Miller, 1995, p. 248; 2001, p. 391). Its acquisition requires a variety of investments (ibid.) that can include deliberate efforts to improve linguistic skills, such as attending a language course, as well as activities that immigrants may not necessarily perceive as language-related, for example, talking to members of the majority population (Kristen, et al., 2016, p. 182). Given the wide range of potentially relevant investments that individuals may engage in before, as well as after migration, language learning is perceived as a cumulative outcome of repeated and prolonged investments in skill-increasing behaviors (Espenshade \& Fu, 1997; Esser, 2006a; 2006b; Kristen, 2019, p. 522).

According to the general model of language acquisition, investments differ depending on the incentives for learning the new language (i.e., the learning motivation), the degree of exposure to this language and the efficiency with which individuals improve their proficiency per unit of exposure (Chiswick \& Miller, 1995; 2001). This model has been applied across disciplines, and many researchers have elaborated on the processes underlying these basic dimensions.

We base our subsequent reasoning both on theoretical arguments discussed in the literature, as well as on the body of empirical evidence accompanying these considerations (for an overview see Kristen, 2019). We start with the premise that the basic processes associated with the three constructs of the model apply rather generally (Esser, 2006a; 2006b; Kristen, et al., 2016, p. 203). That is, immigrants of different origins respond to most of the conditions that are relevant for language learning in rather similar ways. For example, talking to a native speaker or attending a language course increases exposure to the dominant language and should be uniformly beneficial to language learning (e.g., Braun, 2010; Chiswick \& Miller, 2001; Kristen, et al., 2016; Stevens, 1999; van Tubergen, 2010). In a similar vein, individuals who intend to stay and settle down in the destination country, or who feel emotionally attached to the new context should be more inclined (i.e., have greater incentives) to invest in becoming fluent compared to individuals who plan to go back to their origin country or who feel more detached from their destination society (e.g., Espenshade, \& Fu 1997; Kristen, et al., 2016; Phinney, Romero, Nava, \& Huang, 2001; van Tubergen, 2010). The notion of a general logic underlying language fluency also applies to the reasoning on efficiency, meaning that those 
with a greater capacity for learning should become proficient at a faster pace (e.g., Chiswick \& Miller 1995; 2001; Dustmann \& Fabbri, 2003; Espenshade \& Fu, 1997; Stevens, 1999; van Tubergen \& Kalmijn, 2005).

Group-specific patterns may nevertheless occur because distinct immigrant groups have experienced certain situations or particular conditions that are less common in other groups. In other words, whenever different origin groups systematically diverge from each other in characteristics that are relevant for any of the three dimensions of the basic model, a differential pattern is expected to appear. For example, if members of a certain immigrant group are more likely to attend a well-designed language course that is known to be efficient than members of a different immigrant group, these discrepant investments should be reflected in a differential linguistic development.

Given our interest in Syrian refugees and the ways in which their situation diverges from, but also aligns with that of other new arrivals who came to Germany during a similar period, in the following, we highlight a selection of conditions that may set contemporary refugees apart from other recent immigrants.

An important difference concerns refugees' legal status. Until a final decision about their residential status is made, refugees cannot be confident about their prospects of remaining in their destination country. This kind of insecurity should be absent among Italians and Poles who, as members of the European Union, are free to settle down and work anywhere in Europe. Insecurities, in turn, are expected to lead to a more reluctant investment behavior (Hvidtfeldt, Schultz-Nielsen, Tekin, \& Fosgerau, 2018; Kosyakova \& Brenzel, 2020; van Tubergen, 2010).

In addition, post-traumatic stress is more common among individuals who fled their home country in times of war and violent conflict, and who experienced dangerous and life-threatening events on their journey to a different destination (Dietrich, Al Ali, Tagay, Hebebrand, \& Reissner, 2019). Given this greater prevalence of related health problems in refugee populations, and considering that poor mental health is associated with cognitive impairment (Medalia \& Revheim, 2002; Trivedi, 2006), individuals who struggle in this regard, may also be less efficient learners.

An additional efficiency component relates to group differences in the distribution of educational qualifications. Given that educational expansion in Syria has not progressed as far as it has in Italy, Poland, or Turkey, it is hardly surprising that Syrian refugees are on average less educated. The less educated segments of the Syrian refugee population, in addition, include illiterates, while individuals who cannot read and write are virtually non-existent in the other immigrant populations under study. ${ }^{2}$ Accordingly, a lack of formal instruction may impose an extra burden on poorly educated individuals who, due to a disadvantaged starting position, may face greater difficulties when acquiring a new language.

2 According to the World Bank, the most recently available numbers for people aged 15 and older point in Syria to a literacy rate of 81 percent (2004), in Italy of 99 percent (2018), in Poland of 99 percent (2008), and in Turkey of 96 percent (2017; https://data. worldbank.org/indicator/SE.ADT.LITR.ZS). 
Moreover, Syrians in the early months after arrival often stayed in collective accommodation. Living in such circumstances may have restricted their exposure to native speakers. However, most Syrians in our sample had left these centers quite some time before the interview, so that so that they should have no longer been suffering from the disadvantage of being separated from the majority population.

The reception of refugees was accompanied by substantive efforts on the part of the German government to provide language training, and many Syrian refugees made use of these opportunities (Brenzel, et al., 2019, p. 71; Brücker, et al., 2019; Kosyakova \& Brenzel, 2020). Structured exposure in formal settings is known to raise proficiency, so that higher participation rates among Syrian refugees should lead to greater linguistic gains.

Given that being exposed to a new language is of central relevance to its acquisition (Kristen, 2019, p. 524; Braun, 2010; Chiswick, \& Miller, 2001; Stevens, 1999), and in view of recent findings that suggest that language instruction contributes significantly to new immigrants' language fluency (e.g., Brenzel, et al. 2019, pp. 73-78; Kristen, et al., 2016), we further argue that structured exposure as provided by language courses can compensate, to some extent, for a lack of resources that are relevant for learning, such as cognitive skills or cultural capital. Although this reasoning applies to all groups, compensatory processes may be more of an issue among contemporary refugees, considering their oftentimes limited endowment with these resources.

\section{Research questions for the empirical study}

We start the empirical part with an illustration of new immigrants' destination-language proficiency and ask how they perform upon arrival and at the time of the first interview. This initial step allows differences in linguistic skills to be identified between different groups of recent immigrants.

Thereafter, we study a range of conditions that reflect the three constructs of the general model of language acquisition, and analyze whether these conditions are associated with language improvement. Based on this account, as well as on prior research that points to the central role of language exposure, we ask whether certain constellations and certain kinds of exposure are of special relevance to language learning.

In a final step, we take a closer look at group-specific patterns and investigate how Syrian refugees differ from other new immigrants. Correspondingly, we address features that are specific to refugees and investigate their association with proficiency. With this additional step, we also tackle the question of whether different immigrant groups respond in similar ways to the conditions captured by the various indicators of the model of language learning. 


\section{Data and methods}

\subsection{Data}

The empirical study is based on data from the first wave of the ENTRA project ("Recent Immigration Processes and Early Integration Trajectories in Germany"), which were collected in 2019. The ENTRA survey is designed as a two-wave-panel study of selected immigrant groups, in which about 4,600 recent arrivals aged between 18 and 41 were interviewed. At the time of the first survey, they had been living in Germany for between 1 and 52 months. The data collection of the second wave will be completed at the beginning of 2021 .

The ENTRA project covers contemporary refugees from Syria, as well as new immigrants from Italy, Poland and Turkey who came to Germany as labor immigrants, for family reasons or as students. Respondents were sampled based on a two-stage sampling design that was applied separately to each immigrant group. In the first stage, based on registration data from the German Federal Office of Statistics, for each group, we selected the five cities that had the largest immigrant inflows. In the second stage, from the registration data, we drew a random sample of our target persons (i.e., all individuals aged 18 to 41 who had citizenship of a country of origin of interest to us, and who registered in the selected German cities between July 2015 and February 2019). In order to obtain a sufficiently large number of addresses of new immigrants, we requested information from the registry offices twice, in September 2018 and in March 2019. The sample is typical for recent immigrant populations in urban areas, but it is not representative. Representativeness is particularly relevant for the description of characteristics in a population. As this is not feasible with our data, we refrain from pursuing this route. Instead, we concentrate on analyzing how a range of conditions shapes the process of language learning.

All target persons received an invitation letter in their native language in which they were offered a monetary incentive to participate in the study. These letters were dispatched in two batches with a time lag of two months. Respondents could choose to take the survey online, via telephone, or face-to-face. Interviews took on average 43 minutes ( $\mathrm{SD}=24$ minutes), but with variation across modes (i.e., face-to-face interviews took about 15 minutes and telephone interviews about 10 minutes longer than online interviews). Since Turkish and Syrian individuals were asked more questions (e.g., regarding their legal status, or their journey to Germany) their interviews took between 5 and 10 minutes longer than those of the other groups. Face-to-face interviews were predominantly conducted in public spaces such as cafés or parks; only about 30 percent were carried out in the respondents' homes. All interviews were administered in the respective languages (i.e., in Arabic, Italian, Polish, and Turkish). 


\subsection{Measures}

Destination-language proficiency at the time of the first interview is a composite index consisting of information on respondents' self-assessed competences in understanding, speaking, reading, and writing German on a scale from o ("not at all") to 5 ("on a native speaker level"). The measure shows a high degree of internal consistency (Cronbach's alpha $=0.96$ ), with the underlying variables loading on a single factor (eigenvalue $=3 \cdot 54$ ).

We also consider language proficiency at the time of arrival. This measure is based on the more general question of how well respondents knew German before moving to Germany. In contrast to the measurement at the time of the first interview, it does not address different linguistic dimensions, such as speaking or reading. This additional instrument is important to our account in two ways. First, it allows the development of language proficiency to be traced over time (i.e., between entry $\left[\mathrm{t}_{0}\right]$ and the first interview $\left.\left[\mathrm{t}_{1}\right]\right)$. Second, we use it to control for a range of pre-migration conditions that are relevant to the level of proficiency at the time of entry, so that we can concentrate on investments that take place in the early period after arrival.

Table 1: Variable definitions

\begin{tabular}{|c|c|}
\hline Name & Definition \\
\hline $\begin{array}{l}\text { German } \\
\text { language } \\
\text { proficiency } \mathrm{t}_{1}\end{array}$ & $\begin{array}{l}\text { Average score of respondents' self-reporting on how well they can (1) understand, (2) } \\
\text { speak, (3) read, and (4) write German. Answer categories range from o "not at all" to } 5 \\
\text { "on a native speaker level". }\end{array}$ \\
\hline $\begin{array}{l}\text { German } \\
\text { language } \\
\text { proficiency } t_{0}\end{array}$ & $\begin{array}{l}\text { Respondents were asked how well they knew German before they moved to Germany. } \\
\text { Answer categories range from o "not at all" to } 5 \text { "a native speaker level". }\end{array}$ \\
\hline $\begin{array}{l}\text { Intention to stay } \\
\text { in Germany }\end{array}$ & $\begin{array}{l}\text { Respondents were asked how much longer they planned to stay in Germany. They } \\
\text { could indicate (1) a specific time span in years, or one of the following answers: (2) } \\
\text { "less than one year", (3) "it depends on the circumstances", (4) "forever", or (5) "don't } \\
\text { know". We distinguish between } 1 \text { "Temporary" ( } 1 \text { \& 2), } 2 \text { "Depends on circumstances" } \\
(3 \& 5) \text {, and } 3 \text { "Forever" (4). }\end{array}$ \\
\hline $\begin{array}{l}\text { Residence } \\
\text { permit }\end{array}$ & $\begin{array}{l}\text { Distinguishes between } 1 \text { "No permit", } 2 \text { "Pending/tolerated", } 3 \text { “Temporary permit", } \\
\text { and } 4 \text { "Permanent permit" (Turks and Syrians only). }\end{array}$ \\
\hline $\begin{array}{l}\text { Closeness to } \\
\text { Germany }\end{array}$ & $\begin{array}{l}\text { Based on the question "How connected do you feel with Germany?". Answer cat- } \\
\text { egories range from o "I do not feel a connection at all" to } 4 \text { "I feel an extremely close } \\
\text { connection". }\end{array}$ \\
\hline Age & Measured in years. \\
\hline Cognitive skills & $\begin{array}{l}\text { Based on a test assessing perceptual information-processing speed similar to the } \\
\text { Digit-Symbol-Test applied in the German Socio-Economic Panel (Lang et al., 2007). } \\
\text { Respondents had to match symbols with correct numbers using a correspondence } \\
\text { table in which nine symbols are assigned to numbers. In a 90-second task, symbols } \\
\text { were randomly shown and the respondents had to enter the corresponding number } \\
\text { (1-9). Test scores represent the number of correctly solved items. }\end{array}$ \\
\hline
\end{tabular}


Table 1 continued

\begin{tabular}{|c|c|}
\hline Name & Definition \\
\hline Education in $\mathrm{CO}$ & $\begin{array}{l}\text { Highest educational degree completed in country of origin (CO) based on the } \\
\text { ISCED-97 classification. Distinguishes between o "None/primary/lower secondary" } \\
\text { (ISCED 0-2), } 1 \text { "Upper secondary" (ISCED 3-4), and } 2 \text { "Tertiary" (ISCED 5-6). }\end{array}$ \\
\hline Mental health & $\begin{array}{l}\text { Average score of six items of the Kessler Psychological Distress Scale (K-6; Kessler } \\
\text { et al., 2003), e.g., "During the past month, about how often did you feel hopeless?". } \\
\text { Answer categories range from o "almost all of the time" to } 4 \text { "none of the time". }\end{array}$ \\
\hline CO literacy & $\begin{array}{l}\text { Average score of respondents' self-reporting of how well they can (1) read and (2) } \\
\text { write Arabic (Syrians only). Answer categories range from o "not at all" to } 5 \text { "on a } \\
\text { native speaker level". The average scores were assigned to a dummy variable to distin- } \\
\text { guish between respondents who } 1 \text { "can read and write Arabic at least well (i.e., indi- } \\
\text { viduals with an average score of } 3-5 \text { )" and o "score below (o-2.5)". }\end{array}$ \\
\hline Duration of stay & Difference between the date of the interview and the date of arrival (in years). \\
\hline $\begin{array}{l}\text { Investment in } \\
\text { language skills }\end{array}$ & $\begin{array}{l}\text { Respondent were asked whether they had done anything to improve their German } \\
\text { since moving to Germany. If "yes" they were asked to specify their activities (e.g., } \\
\text { "took language classes" or "learned through self-study"). We coded the answers as a } \\
\text { dummy variable, assigning any investment to } 1 \text { except for integration/language cours- } \\
\text { es, which were coded into a separate variable. }\end{array}$ \\
\hline $\begin{array}{l}\text { Language/ } \\
\text { integration } \\
\text { course }\end{array}$ & $\begin{array}{l}\text { Variable indicating whether respondents participated in a German language or inte- } \\
\text { gration course with o "No" and } 1 \text { "Yes". }\end{array}$ \\
\hline $\begin{array}{l}\text { Language } \\
\text { certificate }\end{array}$ & $\begin{array}{l}\text { Highest level of German language certification received (if participated in language/ } \\
\text { integration course) based on the classification of the Common European Framework } \\
\text { of Reference for Languages: o "No course attended", } 1 \text { "None/A1/A2", } 2 \text { "B1/B2", and } \\
3 \text { "C1/C2". }\end{array}$ \\
\hline In education & $\begin{array}{l}\text { Variable indicating whether respondents are currently enrolled in education with o } \\
\text { "No" and } 1 \text { "Yes". }\end{array}$ \\
\hline Employed & $\begin{array}{l}\text { Variable indicating whether respondents are currently working with o "No" and } 1 \\
\text { "Yes". }\end{array}$ \\
\hline Language use & $\begin{array}{l}\text { Respondents were asked how often they speak German with (1) their partner, (2) their } \\
\text { children, (3) friends, (4) other people in everyday life (e.g., colleagues, neighbors), and } \\
\text { (5) how often they watch movies or TV, listen to the radio, read newspapers, maga- } \\
\text { zines or books in German. Answer categories range from o "never" to } 4 \text { "always". }\end{array}$ \\
\hline Partner/children & $\begin{array}{l}\text { Average score of language use with partner (1) and children (2). Respondents without } \\
\text { partner and children were assigned a value of } 0 .\end{array}$ \\
\hline $\begin{array}{l}\text { Friends/other } \\
\text { people }\end{array}$ & Average score of language use with friends (3) and other people (4). \\
\hline $\begin{array}{l}\text { Media } \\
\text { consumption }\end{array}$ & Answer to item (5). \\
\hline
\end{tabular}

To cover the three constructs of the model of language acquisition, we use a range of indicators, many of which are well established in the literature (for an overview, see Kristen, 2019). Table 1 provides the full definitions of all variables, Table 2 information about their distributions according to the different groups of new immigrants. 
Destination-language acquisition of recently arrived immigrants |

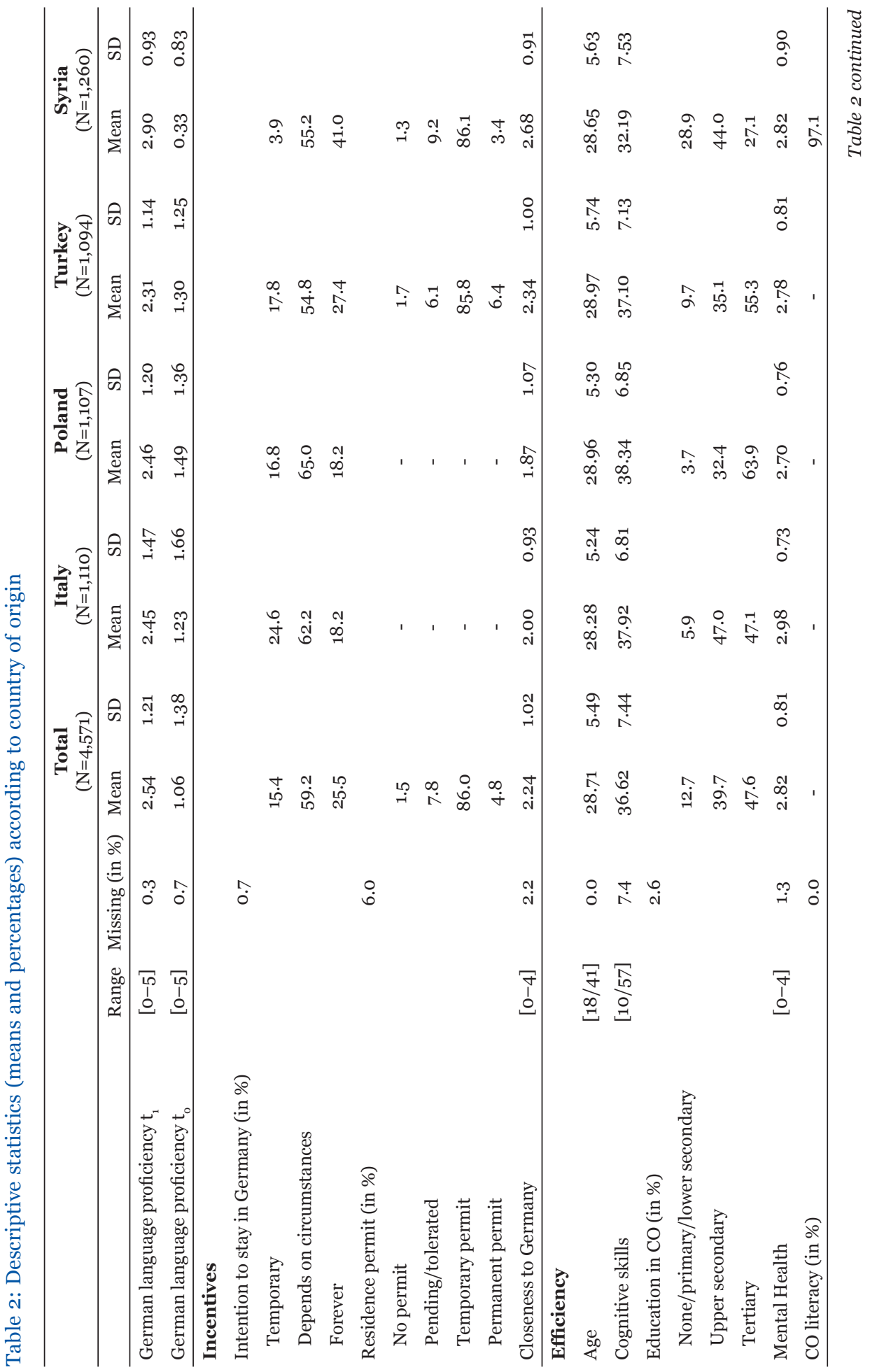


| Cornelia Kristen \& Julian Seuring

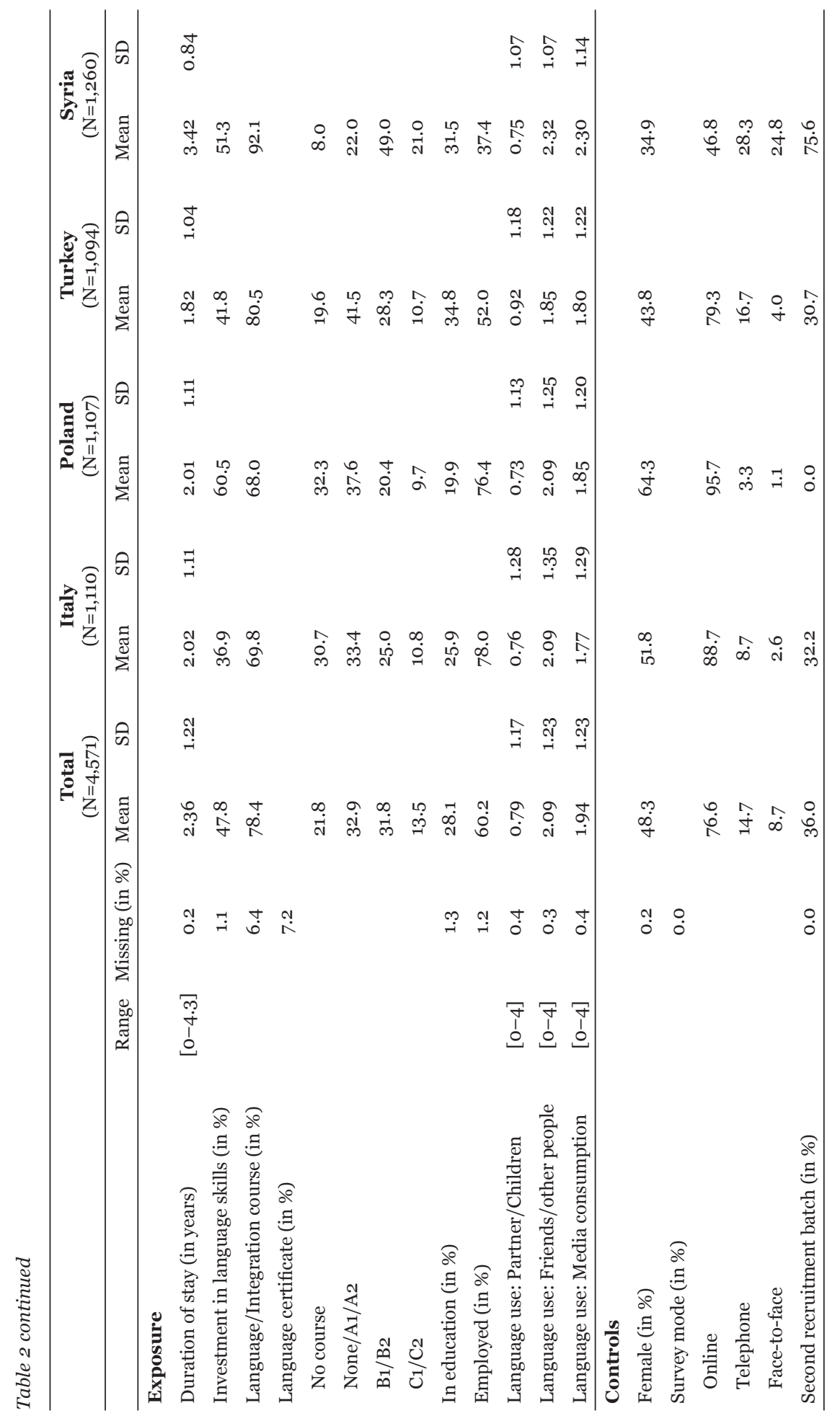

138 | JERO, Vol. 13, No. 1 (2021) 
Regarding incentives, we include the intention to stay in Germany, the type of residence permit, which provides the legal basis for individuals to assess their prospects of permanent residence, as well as the degree of closeness to Germany felt by respondents as an indicator of emotional attachment. In terms of efficiency, we consider the respondent's age, cognitive skills captured using the Symbol-Digit Test (SDT), a speed-constrained measure of information-processing capacities (Lang, Weiss, Stocker, \& von Rosenbladt, 2007) ${ }^{3}$, the level of education acquired in the country of origin (i.e., education in $\mathrm{CO}$ ), and whether the individual had acquired CO literacy. We further consider mental health, as poor mental health is associated with the impairment of cognitive functioning (Medalia \& Revheim, 2002; Trivedi, 2006).

Exposure is measured by the duration of stay at the time of the first interview, by a variable that records whether respondents made any efforts since their arrival to improve their level of proficiency (i.e., investment in language skills), whether they took up a language or integration course and, if so, which language certificate they obtained, whether they are currently in education, and whether they are presently employed. We also include three indicators of language use that are known to be of great importance to acquiring the destination language (Braun, 2010; Chiswick \& Miller, 2001; Espenshade \& Fu, 1997; Kristen et al., 2016; Stevens, 1999): language use with their partner and children, language use with friends and other people, and language use in media consumption.

As controls, we include the respondent's sex, the survey mode (i.e., face-to-face, telephone, or online), and whether the individual belongs to the first or the second recruitment batch. When presenting findings for the whole sample, we also include a control for the country of origin.

\subsection{Analytical strategy}

In the following, we analyze the development of immigrants' destination-language proficiency shortly after their arrival in Germany, applying linear regression. To address item nonresponse, we use multiple imputation and estimate 50 datasets with complete information (Allison, 2001). Following Rubin's (1987) approach, we combine the results of the analyses performed on each dataset. Descriptive results (presented in Table 2 and Figure 1) are based on the original data.

Immigrants in the ENTRA survey arrived in Germany between July 2015 and February 2019. Within this period, Italians, Polish and Turkish immigrants' dates of arrival were spread relatively evenly over the whole time period, while Syrians' dates of arrival were concentrated in the second half of 2015. This is in line with the observation that most refugees from Syria came to Germany in 2015, and that thereafter, there was a substantial decline (Statistisches Bundesamt, 2019).

3 Respondents in the telephone mode were offered an additional incentive to take the test online. They received an email with a link to the test and then participated in the same way as in the regular online mode. 
These group-specific entry patterns are reflected in a longer average duration of stay ( $M=41$ months) and a smaller dispersion of this measure ( $S D=10$ months) among Syrians compared to the other immigrant groups ( $M=24$ months for Italians and Poles and $M=22$ months for Turkish respondents, $S D=13$ months for all groups). Therefore, characteristics that are typically related to the duration of stay will also vary less among Syrians. This reduced variation can affect estimations of the associations of these variables with destination-language proficiency. They might turn out to be smaller among Syrians than they would have been if the data contained a more dispersed distribution of Syrian immigrants across the full range of the arrival spectrum.

\section{Results}

\subsection{Destination-language proficiency upon arrival and at the time of the first interview}

Figure 1 illustrates the development of new immigrants' self-assessed Germanlanguage proficiency. Each line represents a single immigrant. Its onset indicates the proficiency level at the time at which the individual entered Germany; the end of the line indicates the proficiency level at the time at which the interview took place. Given that individuals in our sample immigrated between July 2015 and February 2019, the lines can start anywhere within this spectrum. The end points concentrate in 2019, when the interviews were conducted.

In addition to illustrating individual developments, Figure 1 for each group includes the overall trend (i.e., the red dashed line). For each immigrant group, the red dashed line depicts the average change in fluency that took place in the early period after arrival. The onset and the end of the trend lines correspond to the averages specified in the first two rows of Table 2.

The first important finding is that almost everyone gains proficiency over time. Among Syrians, the trend line and many of the underlying single lines are steeper than those of the other groups. A reason for this pattern could be that Syrians were far more likely to be entering Germany much with no German language skills, while Italian, Polish and Turkish immigrants had more frequently already acquired some German before migrating. Typically, when learning a new language from scratch, rapid progress is made, and the learning curve is steeper than among those who already have acquired a certain skill level (Hartshorne, Tenenbaum, \& Pinker, 2018). This reasoning is also supported by the finding that group differences in proficiency levels are less pronounced at the time of the first interview than upon arrival. 


\section{Destination-language acquisition of recently arrived immigrants}

Figure 1: Destination-language proficiency upon arrival and at the time of the first interview

a. Italy

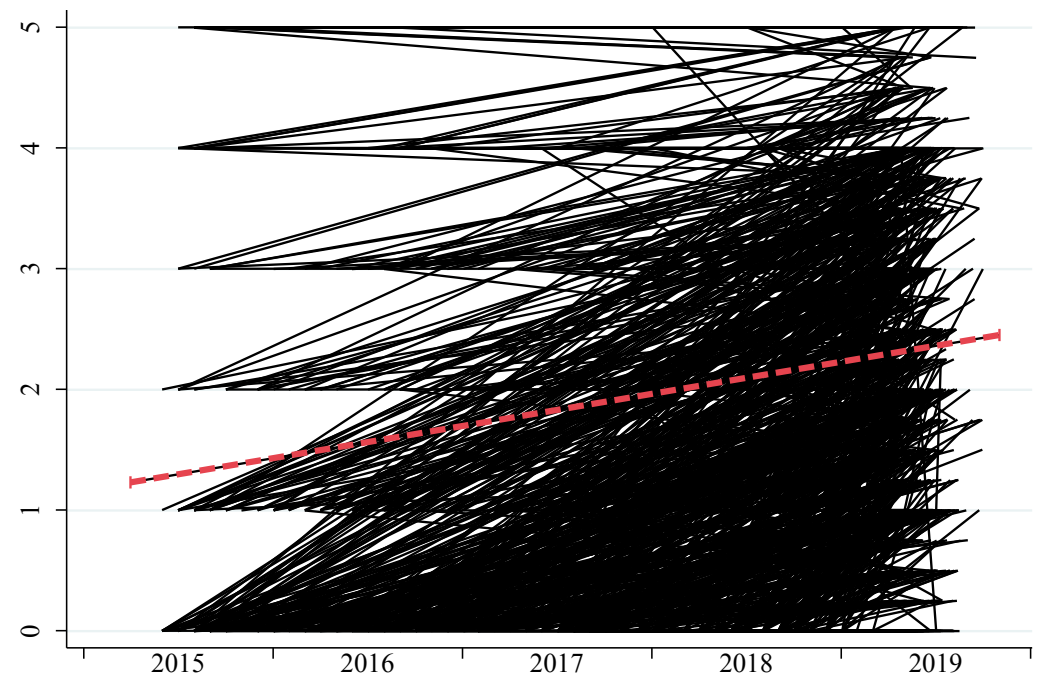

b. Poland

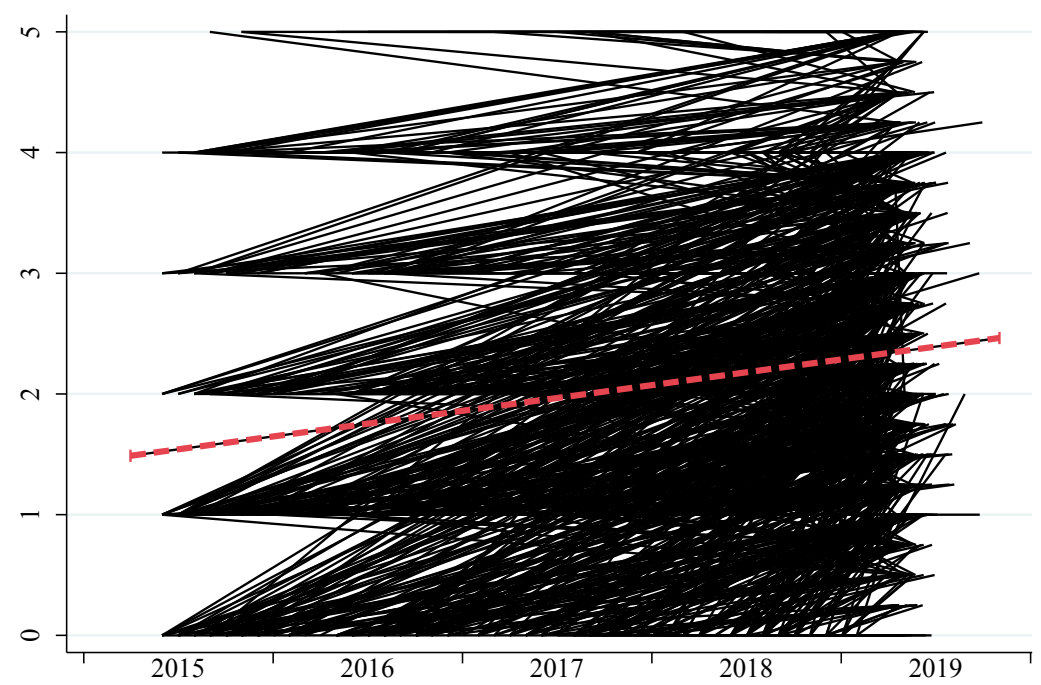

Figure 1 continued 
Cornelia Kristen \& Julian Seuring

Figure 1 continued

c. Turkey

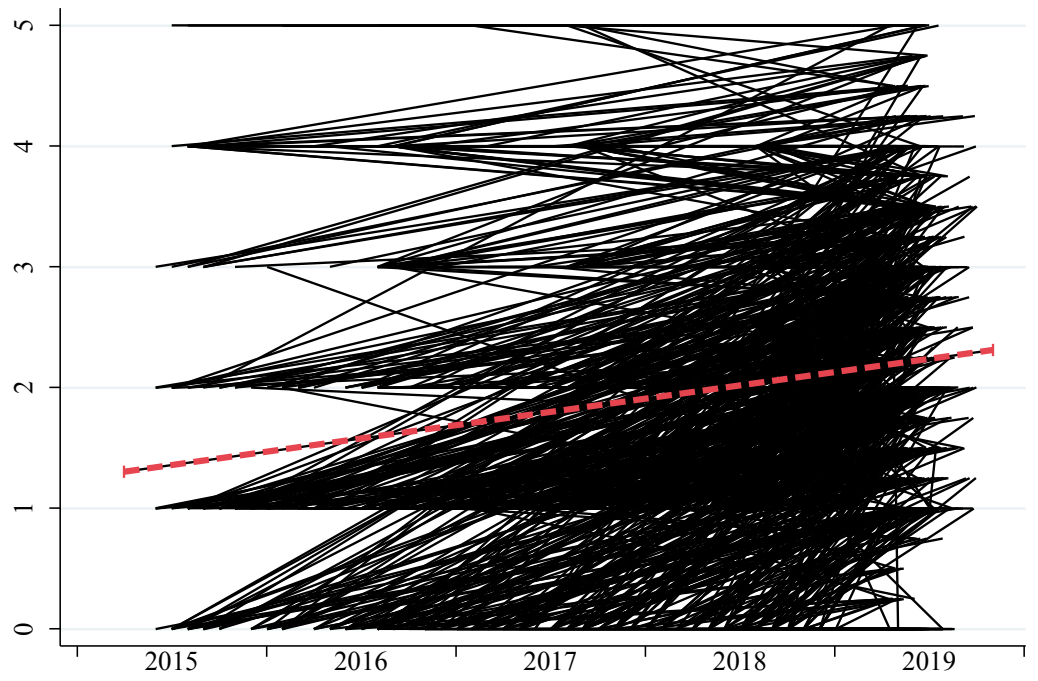

d. Syria

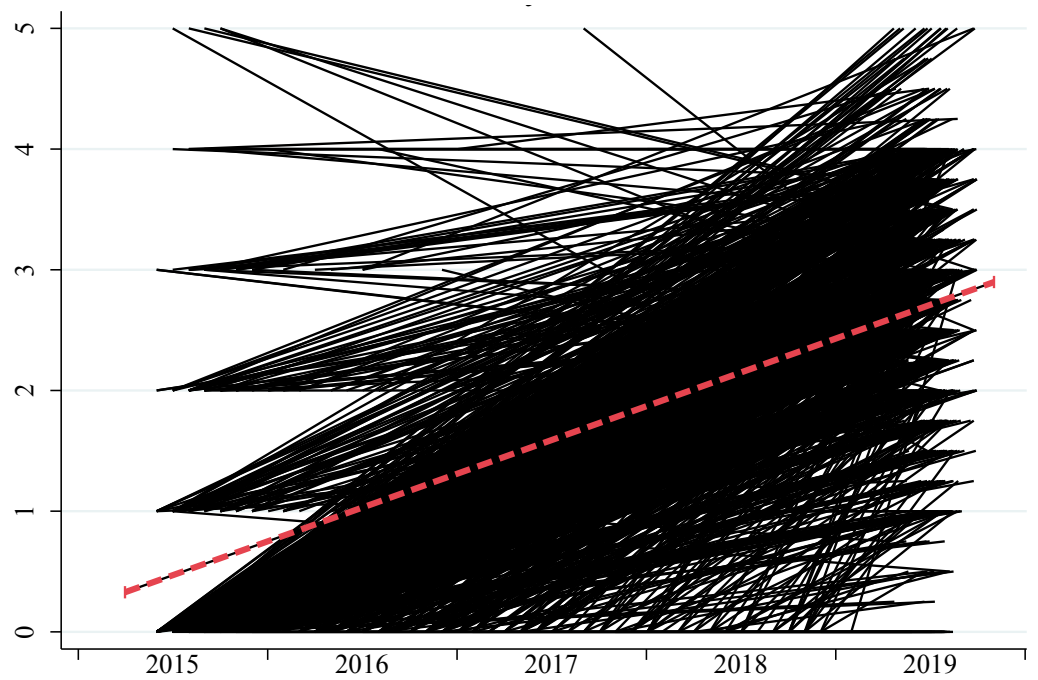




\subsection{Empirical findings on the conditions shaping destination- language proficiency}

Following the assumption that immigrants of different origins who came to Germany for different reasons respond to most of the conditions that are relevant for language learning in rather similar ways, we start by presenting findings on the pooled sample before we move on to discuss group-specific patterns.

Table 3 presents the results of linear regressions of destination-language proficiency ordered according to the three constructs of the general model of language acquisition. The empirical evidence on the relevance of incentives is less consistent than it is for the other two constructs of efficiency and exposure (Model 1). Contrary to the expectation that those who intend to stay in Germany forever, rather than temporarily, are more motivated to learn German and therefore achieve greater fluency, we find a negative coefficient, which suggests that the reverse is true. ${ }^{4}$ In terms of emotional attachment, the results are in line with our reasoning: they indicate that individuals who feel close to Germany display a greater improvement in language proficiency. These opposing patterns reflect the results of other empirical studies, which point to inconsistent evidence on incentives (e.g., Espenshade, \& Fu, 1997; Kristen et al., 2016; van Tubergen, 2010). One reason contributing to these inconsistencies could be that it is difficult to disentangle motivation from exposure components, especially in a cross-sectional design. As such, the intention to stay may work as an incentive for improving language skills and provide the basis for self-selection into contexts that offer exposure to the dominant language. Therefore, in a model that at the same time captures exposure and incentives, it can be difficult to isolate these temporally intertwined components. ${ }^{5}$

In contrast to the evidence on motivational features, the results on efficiency largely correspond to the findings of previous studies. Immigrants who arrive at a younger age learn a new language faster. In a similar vein, the better educated and those with greater cognitive skills show greater language improvements, possibly due to an enlarged capacity for learning. For mental health, in contrast, we do not find an association with language proficiency.

The third construct, exposure, is the key to acquiring a new language. This is abundantly clear in our study. The coefficients for almost all conditions that signal exposure to German-speaking environments are significant, and point in the expected direction. A longer duration of stay, making an effort to improve one's skills including taking up language courses, attending an educational institution and, above all, language use are all positively related to language acquisition. In relative terms, the use of German outside the core family is one of the most important conditions for learning the new language (not shown here). The only exception to the

4 This counterintuitive result remains unaltered when excluding feelings of closeness to Germany from the model (not shown here).

5 In a separate analysis (not shown here), we excluded the variables on exposure from Model 1. In this case, the negative coefficient for those who intend to stay forever changes into a non-significant positive coefficient. 


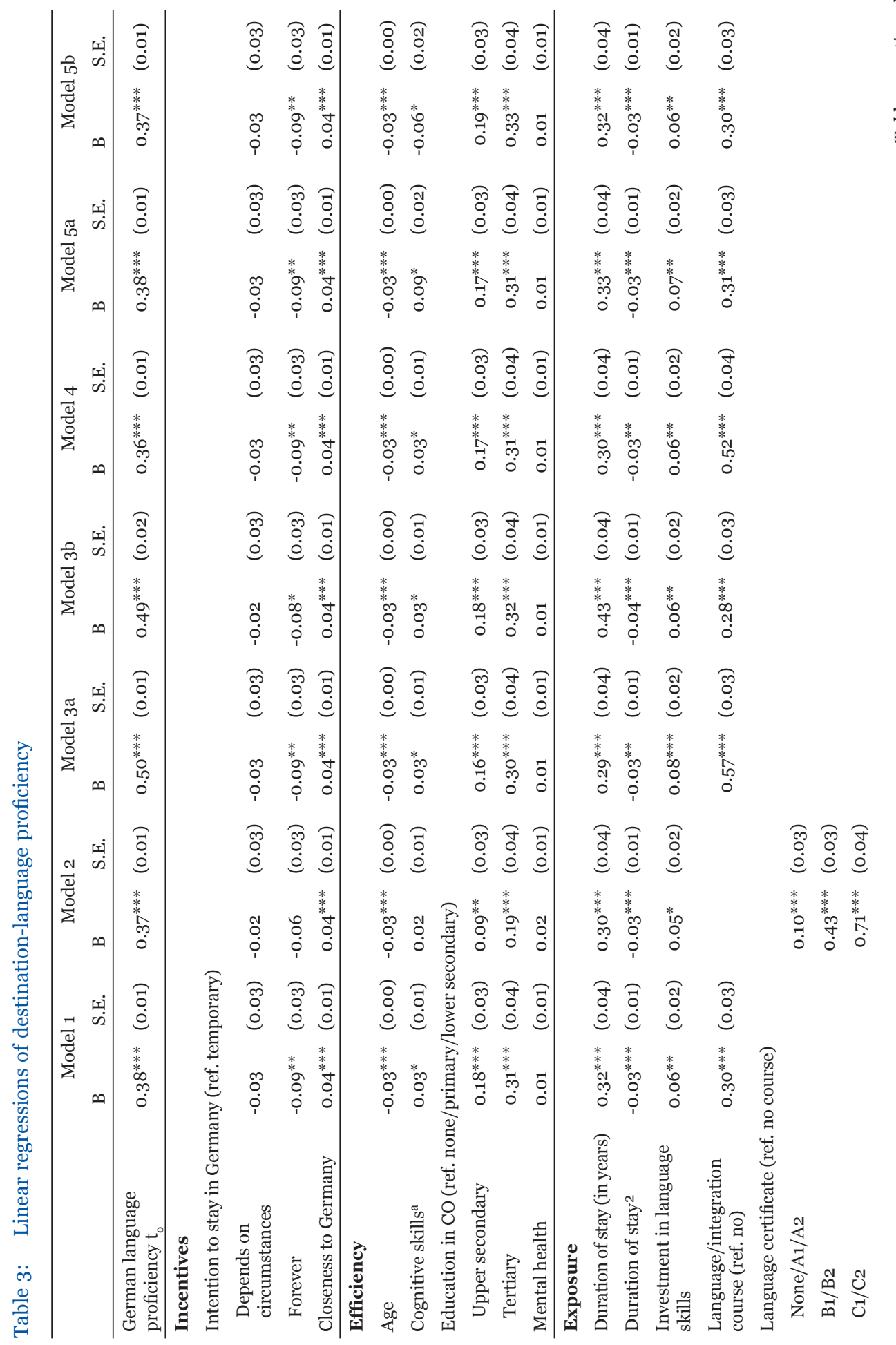




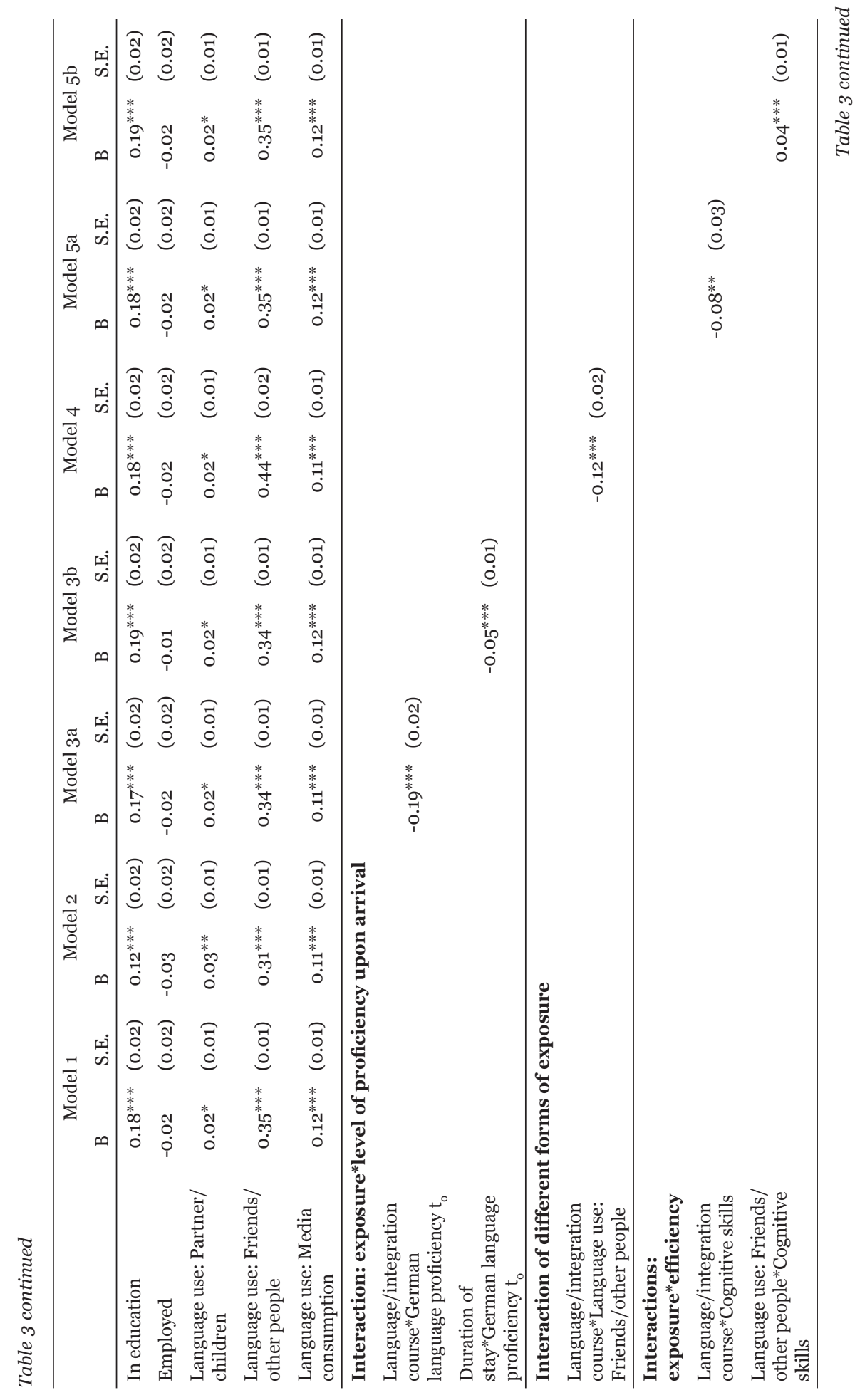




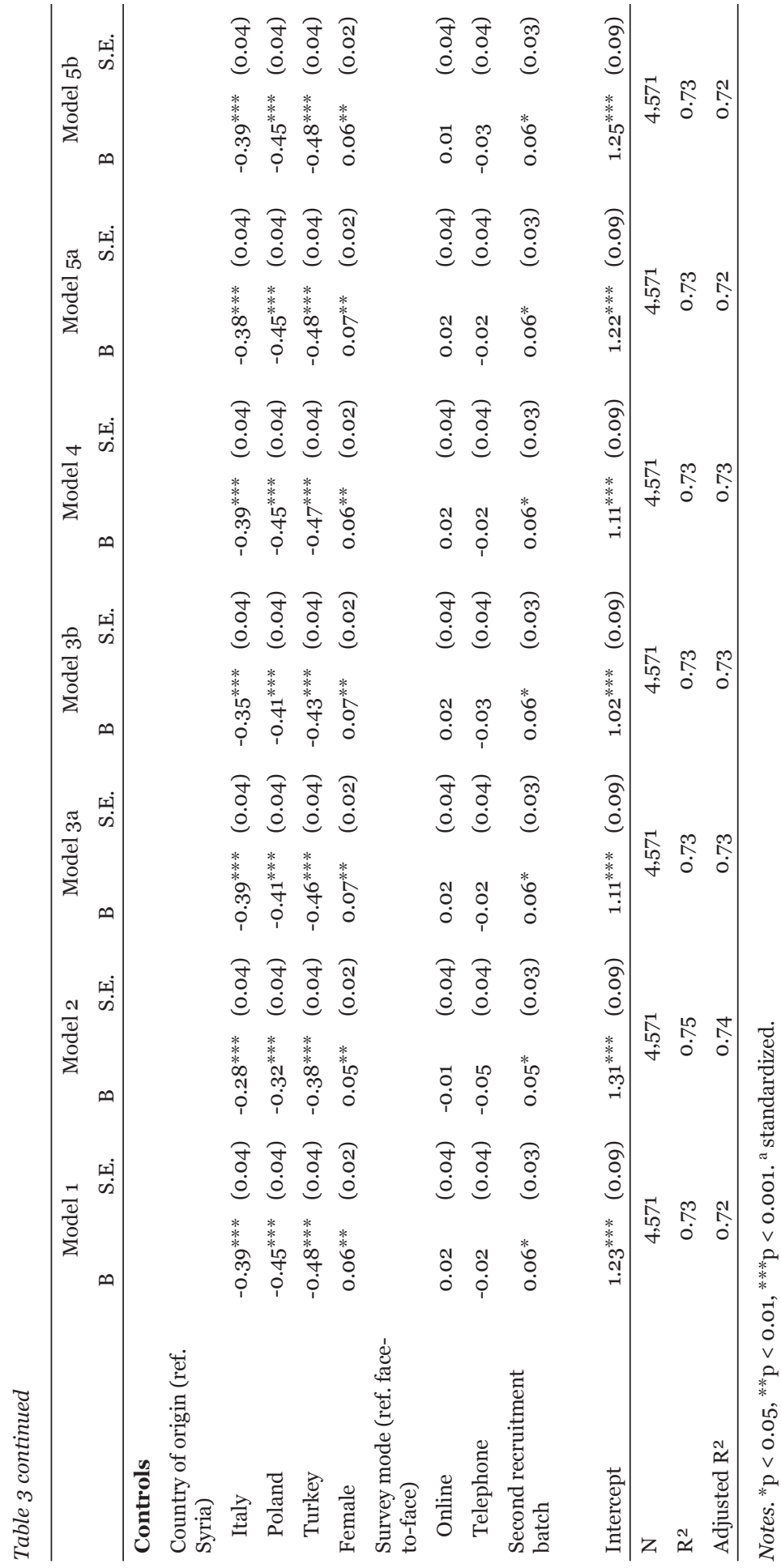

146 | JERO, Vol. 13, No. 1 (2021) 
general pattern that more exposure yields greater improvement is that we do not find an additional positive relationship for individuals who are currently working.

In Models 2 to 5, we take a closer look at language exposure and investigate whether certain constellations and certain kinds of exposure are particularly relevant to language learning. Model 2 expands on attending language and integration courses by introducing the certificates obtained in these classes. The idea is that individuals who attain a higher qualification experience longer spells of structured learning, which should yield greater improvement. The findings illustrate that this is the case: the higher the certificate obtained, the better the level of self-assessed proficiency.

In addition, the interaction incorporated into Model 3a indicates that the immigrants in our sample who came to Germany with low levels of initial destination-language proficiency profited most from attending language and integration courses. Conversely, individuals who already possess a certain level of German language skills when they arrive do not benefit as much from joining language classes. Model 3b points to a very similar result: a longer duration of stay, which is associated with an increasing exposure to the destination language, is more profitable for individuals who arrive with little knowledge of German, whereas the linguistic gains are smaller for immigrants who enter the host country with better skills.

The interaction recorded in Model 4, moreover, illustrates that different forms of exposure can compensate for each other. That means that, for individuals who regularly speak German with friends, neighbors or colleagues, attending a language course is less important than for immigrants who have less contact with native speakers, and vice versa. Similarly, Model 5a indicates that individuals who are located in the lower part of the cognitive skill distribution benefit more from joining language classes than those at the upper end of the distribution. Taken together, courses which provide a structured environment for acquiring the destination language seem to be particularly important for its acquisition. They can also compensate to some extent for a lack of exposure to the new language in daily contacts, and for lower levels of learning efficiency as captured in the measure of cognitive skills.

Model 5b presents a second interaction between exposure and efficiency. It portrays the reversed notion, namely, that those with greater cognitive skills could be better equipped to make use of the language input available in their environment. The result supports this reasoning. Individuals who achieve higher scores on the cognitive test profit more from talking in German to friends and other people. The differential patterns found in Model $5 \mathrm{a}$ and $5 \mathrm{~b}$, which both address the interplay of exposure and efficiency, seem to point to a substantive difference between exposure taking place in a structured context, such as a language class, and exposure that is a byproduct of everyday communication. While the former can have a compensatory function supporting especially those with lower cognitive skills, the latter, less structured way of exposure to native speakers, is more profitable for more efficient learners. 


\subsection{How do Syrian refugees differ from other new immigrants?}

Table 4 shifts the focus towards group-specific patterns. Rather than discussing the whole range of findings, in the following, we concentrate on features that set Syrian refugees apart from new immigrants from Italy, Poland, and Turkey. While the variables included in Models 6 to 9 are identical to those of Model 1, in Table 3 , Model 10 expands the analyses of Syrians with two additional variables.

To start, we investigate whether Syrians differ from other immigrants regarding the conditions of language learning in terms of incentives. The findings of the multivariate account presented in Table 4, however, are revealed to be rather similar to those reported before, when considering the overall sample (see Model 1 in Table 3). We find that, in most groups, individuals who feel close to Germany achieve greater language improvements, while contrary to our expectations, individuals who intend to stay in the destination country forever do not perform better than those who anticipate leaving at some point in the future.

In Model 10, we additionally take into account the kind of residence permit that Syrian refugees had obtained at the time of the interview. It becomes evident that any legal situation of insecurity is negatively related to language proficiency. Note that it is not possible to include this indicator for Poles and Italians who, as members of the European Union, are free to move and settle anywhere in Europe. For Turkish immigrants, who come from a third country and therefore also need a residence permit, we find a similar, though less pronounced, negative relationship similar to that for Syrians (not shown here).

In a next step, we take a closer look at the set of efficiency variables. Model 9 shows that educational qualifications are strongly connected to German language proficiency among Syrians, but not among any of the other new arrivals (Models 6-8). However, educational qualifications may not always indicate the same level of skills or knowledge across countries. Instead, they need to be evaluated in light of the context in which they were acquired (Spörlein \& Kristen, 2019; Spörlein, Kristen, Schmidt, \& Welker, 2020). If a certain level of formal education is required for learning a new language, and almost everyone in a population has acquired this basic level of formal education, additional educational qualifications may not provide an extra advantage. If, however, this level has not yet been reached by large parts of a population, we might see an advantage for language acquisition rather in the lower educated-segments.

In Model 10, we further pursue this reasoning by including a measure of literacy in the origin language as an additional feature for Syrians, which may allow setting further apart individuals in the lower spectrum of formal education. On the one hand, the findings indicate that Syrian refugees with rather poor reading and writing skills seem to face particular difficulties when learning German. On the other hand, when taking into account this condition, the coefficients for educational qualifications decrease in size. These findings provide some support for our reasoning, but they do not fully account for the finding that educational qualifications matter particularly for Syrians. 
Destination-language acquisition of recently arrived immigrants |

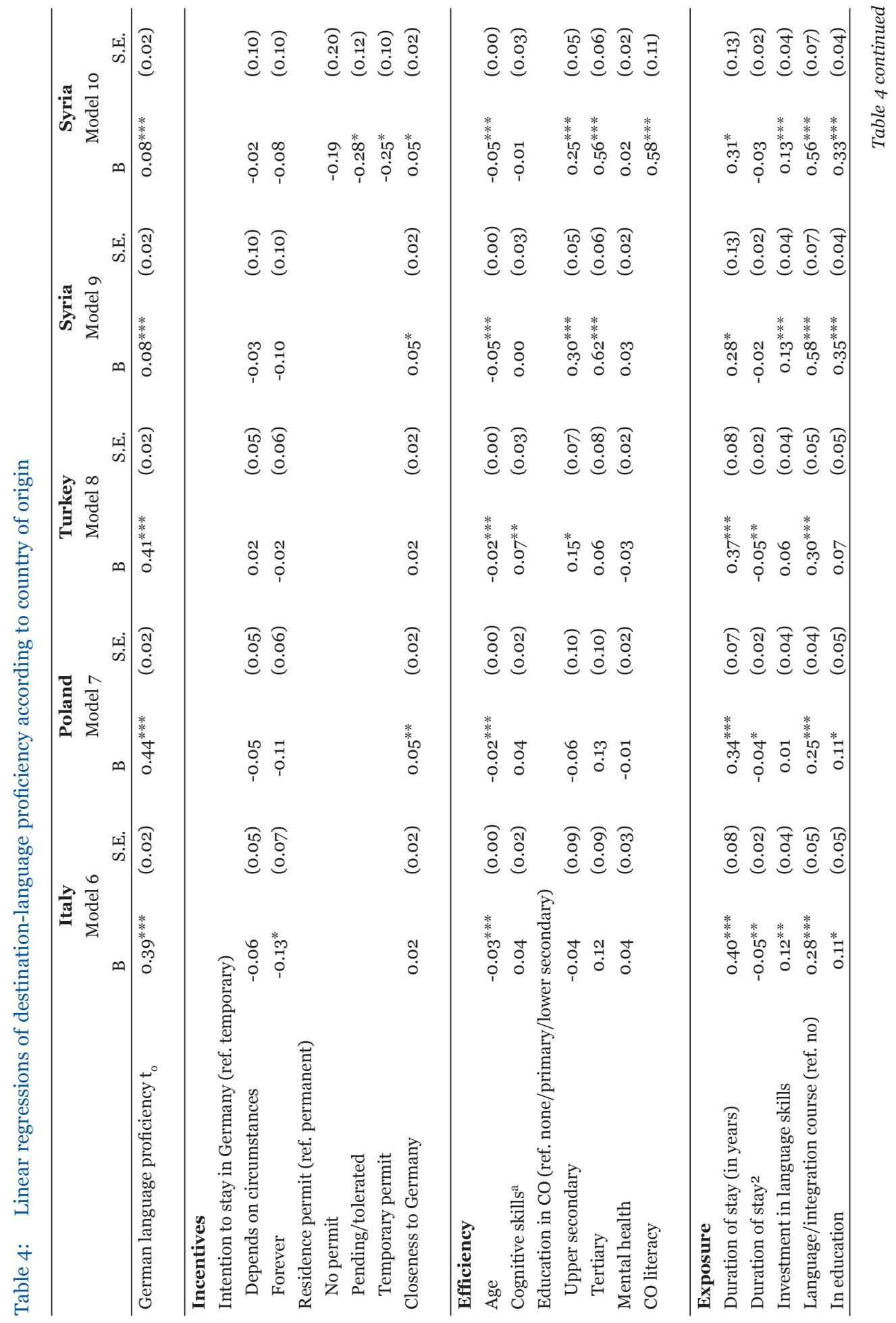


| Cornelia Kristen \& Julian Seuring

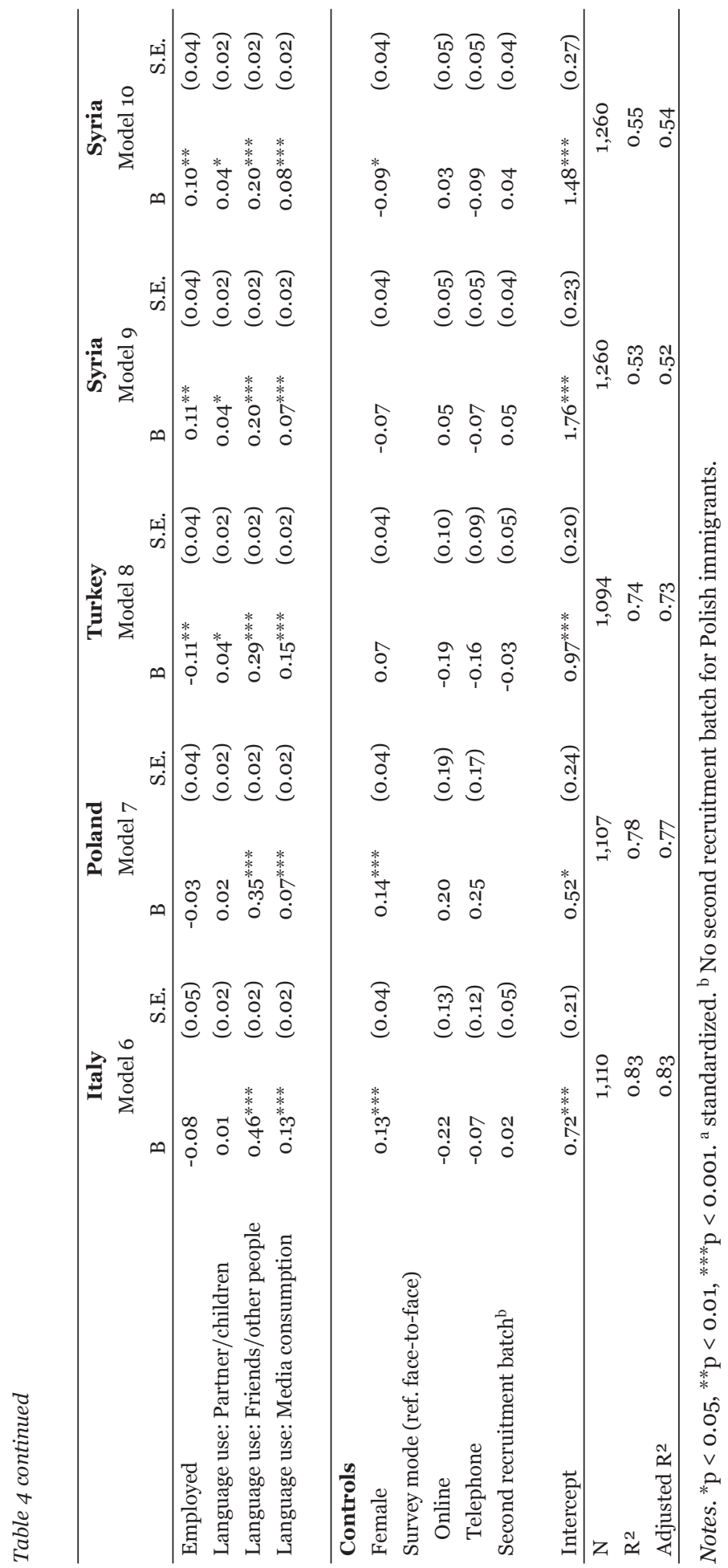

150 | JERO, Vol. 13, No. 1 (2021) 
For other indicators of efficiency, the results reveal rather similar patterns to those observed in the pooled sample. As numerous previous empirical studies have found (e.g., Chiswick \& Miller, 1995; 2001; Espenshade \& Fu, 1997; Stevens, 1999), age is negatively related to language proficiency. Contrary to our expectations, we do not encounter a health-related disadvantage for any group, including Syrian refugees.

Finally, the results on exposure reflect those obtained for the pooled sample: the different immigrant groups, by and large, respond rather similarly to the conditions captured by the various indicators. Probably the most important observation in this context is that Syrian refugees seem to profit more than other groups from certain kinds of exposure, such as from attending language courses, from pursuing further education, and from working. Given that upon arrival, many Syrians hardly knew any German, their continued exposure to structured learning environments, such as those encountered in educational institutions or language courses, seems to have paid off. This assessment is also reflected in the descriptive findings presented in Table 2. They illustrate that with 92 percent Syrian refugees were more likely to attend a language or integration course than individuals from any other group (i.e., 70 percent among Italian immigrants, 68 percent among Polish immigrants, and 81 percent among Turkish immigrants) and that, in these classes, larger shares than in all other groups achieved at least an intermediate certificate (i.e., 70 percent of Syrian refugees at achieved at least B1, versus 36 percent of Italian immigrants, 30 percent of Polish immigrants, and 39 percent of Turkish immigrants).

Overall, the set of variables that we considered to capture the three constructs of the general model of language learning account for large parts of the variance in language development. $\mathrm{R}^{2}$, however, turns out to be smaller for Syrian refugees than it does for the other immigrant groups. This is at least partly linked with the fact that most Syrians arrived in Germany without any knowledge of German, while in the remaining groups, destination-language proficiency was more dispersed, with many having acquired at least some skills (see Table 2 and Figure 1). In other words, compared to other recent immigrants, Syrians were concentrated at the lower end of the linguistic skill distribution, and thus showed less variance in their initial levels of proficiency. Therefore, considering initial language skills in the regression models produces a considerable increase in $\mathrm{R}^{2}$ for all groups, except for Syrian refugees.

\section{Conclusions}

This contribution addressed immigrants' destination-language acquisition in the early period after arrival. In addition to describing patterns of linguistic fluency, we focused on a range of conditions relevant for learning a new language. Based on Chiswick and Miller's (1995; 2001) well-established model of language acquisition, according to which language fluency is a function of exposure, efficiency, and in- 
centives, we discussed a selection of these conditions. We then applied the reasoning to different groups of contemporary immigrants and contrasted Syrian refugees with individuals from Italy, Poland and Turkey. In the following, we highlight and discuss the main findings.

First, most individuals improve their proficiency over time. The results point to a steeper learning curve among Syrians compared to other groups of new immigrants. Part of this difference seems to be attributable to the fact that most Syrian refugees arrived without any prior knowledge of German and that those learning a new language from scratch tend to experience faster initial improvements (Hartshorne, Tenenbaum, \& Pinker, 2018). However, considering that the initial measurement of linguistic skills at the time of entry $\left(\mathrm{t}_{\mathrm{o}}\right)$ was assessed in hindsight at the time of the first interview $\left(\mathrm{t}_{1}\right)$, it may be preferable to first ensure that a differential pattern is indeed present before further speculating about its origins. It will be possible to provide a more appropriate description of the developments of destination-language skills once the second wave of the ENTRA survey is completed. This second data collection, in which respondents will report on their skills based on the same measurement as in the first interview, will allow new immigrants' gains in proficiency to be assessed over time and for possible differential learning pathways to be identified across different groups of recent immigrants.

Second, our multivariate results in largely reflect the findings of previous studies. This assessment applies to all three dimensions of the model of language acquisition. Our analyses point to the relevance of a range of established indicators signaling efficiency and, above all, exposure. Regarding incentives, the empirical evidence turned out to be less consistent and partly divergent from the theoretical expectations. It should be kept in mind, however, that inconsistencies and contradictory findings are typical for empirical studies that consider incentives (for a summary of this evidence see Kristen, 2019, p. 525).

Third, regarding the relative importance of the three dimensions of language learning, our empirical analyses attest to the central relevance of exposure to the dominant language compared to conditions that signal efficiency and incentives. This finding is in line with a large body of results which illustrate that exposure is the major source of destination-language proficiency (e.g., Braun, 2010; Chiswick \& Miller, 1995; 2001; Espenshade \& Fu, 1997; Kristen et al., 2016; Stevens, 1999; van Tubergen \& Kalmijn, 2005).

Fourth, considering the significance of new language exposure, we analyzed different kinds of exposure and distinguished between structured input taking place in language courses or within educational institutions, and everyday communication via contact with native speakers. The evidence attests to the crucial importance of both. However, our findings also indicate that, for immigrants who arrive with minimal or without any prior knowledge of German, or who are located in the lower parts of the cognitive skill distribution, attending language classes can be especially profitable. Consequently, providing new immigrants with opportunities for language instruction seems to be a promising way of supporting especial- 
ly those individuals who are less privileged in terms of their learning resources endowments.

Fifth, as initially proposed, the results clearly support the assumption that language learning is a process that follows a general logic (Kristen et al., 2016, p. 203). Given similar conditions and experiences, individuals attain similar levels of proficiency, no matter where they originate from or for what reasons they leave their home country.

Sixth, we argued that group-specific patterns can nevertheless occur because Syrian refugees may have encountered certain kinds of situations or conditions more frequently than Italian, Polish or Turkish new immigrants. Along these lines, our analyses revealed that an insecure legal status, which is more common among Syrians, is negatively associated with language acquisition. Considering that, as contemporary refugees, Syrians are more likely to have experienced violent conflict as well as danger on their journey to Europe, we expected them to more commonly experience mental health problems and for their language acquisition to suffer as a consequence. The empirical findings, however, did not confirm either phenomenon. While other data sources mostly point to a higher prevalence of mental health issues among recent refugees, and therefore differ from the distributions presented here (Brücker, Rother, \& Schupp, 2016, p. 86), studies that examine the relationship between mental health and language learning are rare and provide inconclusive evidence (e.g., van Tubergen, 2010).

Seventh, and contrary to our expectations, the results also pointed to seemingly differential relationships between certain conditions and language proficiency across groups. On the one hand, the results revealed that it is only among Syrian refugees that educational qualifications acquired in the country of origin are associated with German-language skills, while this relationship was largely absent in the other groups. On the other hand, Syrians profited more than other new arrivals from increased levels of exposure to the new language, including attending language classes, pursuing further education, and working. Especially at low levels of initial proficiency, immediate and sustained exposure to structured learning environments seems to be a promising route to language acquisition.

So far, we were only able to analyze the first wave of the ENTRA survey. Only after the completion of the second data collection, will it be possible to clarify whether the observed differential relationships with proficiency that seem to set Syrian refugees apart from Italian, Polish and Turkish immigrants, also manifest longitudinally. The longitudinal perspective is also crucial for moving away from mere descriptions of associations to tackling the causal relationships that are proposed by the model of language acquisition. This also includes addressing reciprocal relations. For example, in our study the relationship between employment and language skills could go in both directions. On the one hand, a certain level of proficiency is required for entering the labor market, and those with better skills are more likely to be employed. On the other hand, employment may provide exposure to the destination language, and therefore contributes to improving language skills further. 
Another limitation concerns the dependent variable, which was based on respondents' self-assessed proficiency. Research shows that these reports do not fully match actual skills as measured by standardized tests, and that they can be, to some extent, biased (Edele, Seuring, Kristen, \& Stanat, 2015). The situation in our case might be further complicated by the fact that the groups under study differ in proficiency levels. If the extent of the bias were connected to certain skill levels, this would affect our analyses. For example, Syrian refugees mostly arrived with absent or very low levels of initial German-language proficiency, while the remaining immigrant groups show a greater degree of dispersion in language fluency upon entry. If a certain kind of bias is typical for individuals who start learning a new language (e.g., that they perceive their progress to be greater than it actually is), this could lead to group differences, such as the steeper learning curve observed for Syrian refugees. This limitation seems particularly relevant for descriptive analyses of the development of language skills over time and across immigrant groups. It should be, however, less problematic for our multivariate analyses, in which we account for initial levels of destination-language proficiency and for other factors that might introduce bias such as cognitive skills. Moreover, we calculated separate regression models for each immigrant group. These analyses should not be affected by potential group-specific bias.

\section{Acknowledgments}

The authors acknowledge the financial support from the Deutsche Forschungsgemeinschaft (DFG, project number KR 3766/9-1). The responsibility for the content of this publication lies with the authors.

\section{References}

Alba, R. (2005). Bright vs. blurred boundaries: Second-generation assimilation and exclusion in France, Germany, and the United States. Ethnic and Racial Studies, 28(1), 20-49. https://doi.org/10.1080/0141987042000280003

Alba, R., Sloan, J., \& Sperling, J. (2011). The integration imperative: The children of low-status immigrants in the schools of wealthy societies. Annual Review of Sociology, 37, 395-415. https://doi.org/10.1146/annurev-soc-081309-150219

Allison, P. D. (2001). Missing data. Thousand Oaks, CA: Sage.

Azzolini, D., Schnell, P., \& Palmer, J. R. B. (2012). Educational achievement gaps between immigrant and native students in two 'new' immigration countries: Italy and Spain in comparison. Annals of the American Academy of Political and Social Science, 643(1), 46-77. https://doi.org/10.1177/0002716212441590

Braun, M. (2010). Foreign language proficiency of intra-European migrants: A multilevel analysis. European Sociological Review, 26(5), 603-617. https://doi. org/10.1093/esr/jcpo52

Brenzel, H., Brücker, H., Fendel, T., Guichard, L., Jaschke, P., Keita, S., Kosyakova, Y., Olbrich, L., Trübswetter, P., \& Vallizadeh, E. (2019). Flüchtlingsmonitoring: Endbericht. Berlin: Bundesministerium für Arbeit und Soziales, Forschungsbericht, 528. 
Brücker, H., Croisier, J., Kosyakova, Y., Kröger, H., Pietrantuono, G., Rother, N., \& Schupp, J. (2019). Second wave of the IAB-BAMF-SOEP Survey: Language skills and employment rate of refugees improving with time. IAB Brief Report (3), 1-19.

Brücker, H., Rother, N., \& Schupp, J. (2016). IAB-BAMF-SOEP-Befragung von Geflüchteten: Überblick und erste Ergebnisse. IAB Forschungsbericht 14. Retrieved from http://doku.iab.de/forschungsbericht/2016/fb1416.pdf

Chiswick, B. R., \& Miller, P. W. (1995). The endogeneity between language and earnings: International analyses. Journal of Labor Economics, 13(2), 246-288. https://doi.org/10.1086/298374

Chiswick, B. R., \& Miller, P. W. (2001). A model of destination-language acquisition: Application to male immigrants in Canada. Demography, 38(3), 391-409. https:// doi.org/10.2307/3088354

Crul, M., \& Vermeulen, H. (2003). The second generation in Europe. International Migration Review, 37(4), 965-986. https://doi.org/10.1111/j.1747-7379.2003. tbo0166.x

Dietrich, H., Al Ali, R., Tagay, S., Hebebrand, J., \& Reissner, V. (2019). Screening for posttraumatic stress disorder in young adult refugees from Syria and Iraq. Comprehensive Psychiatry, 90, 73-81. https://doi.org/10.1016/j.comppsych.2018.11.001

Dustmann, C., \& Fabbri, F. (2003). Language Proficiency and labour market performance of immigrants in the UK. The Economic Journal, 113(July), 695-717. https://doi.org/10.1111/1468-0297.to1-1-00151

Edele, A., Seuring, J., Kristen, C., \& Stanat, P. (2015). Why bother with testing? The validity of immigrants' self-assessment of language proficiency. Social Science Research, 52, 99-123. https://doi.org/10.1016/j.ssresearch.2014.12.017

Espenshade, T. J., \& Fu, H. (1997). An analysis of English-language proficiency among U.S. immigrants. American Sociological Review, 62(2), 288-305. https://doi. org/10.2307/2657305

Esser, H. (2006a). Sprache und Integration: Die sozialen Bedingungen und Folgen des Spracherwerbs von Migranten [Language and integration: The social conditions and consequences of immigrants' language acquisition], Frankfurt: Campus.

Esser, H. (2006b). Migration, language and integration, AKI-Research Review 4, Berlin. https://bibliothek.wzb.eu/pdf/2006/ivo6-akibilanz4b.pdf

Hartshorne, J. K., Tenenbaum, J. B., \& Pinker, S. (2018). A critical period for second language acquisition: evidence from 2/3 million English speakers. Cognition, 177, 263-277. https://doi.org/10.1016/j.cognition.2018.04.007

Hvidtfeldt, C., Schultz-Nielsen, M. L., Tekin, E., \& Fosgerau, M. (2018). An estimate of the effect of waiting time in the Danish asylum system on post-resettlement employment among refugees: Separating the pure delay effect from the effects of the conditions under which refugees are waiting. PLOS ONE, 13(11), 4-8. https://doi. org/10.1371/journal.pone.0206737.

Kessler, R. C., Barker, P. R., Colpe, L. J., Epstein, J. F., Gfroerer, J. C., Hiripi, E., Howes, M. J., Normand, S. L., Manderscheid, R. W., Walters, E. E., \& Zaslavsky, A. M. (2003). Screening for serious mental illness in the general population. Arch Gen Psychiatry, 6o(2), 184-189. https://doi.org/10.1001/archpsyc.60.2.184

Kogan, I., \& Kalter, F. (2020). An empirical-analytical approach to the study of recent refugee migrants in Germany. Soziale Welt, 71(1-2), 3-23. https://doi. org/10.5771/oo38-6073-2020-1-2-3

Kosyakova, Y., \& Brenzel, H. (2020). The role of length of asylum procedure and legal status in the labour market integration of refugees in Germany. Soziale Welt, 71(12), 123-159. https://doi.org/10.5771/0038-6073-2020-1-2-123

Kristen, C. (2019). Language assimilation and the education of immigrant students. In R. Becker (Ed.), Research Handbook on the Sociology of Education (pp. 519- 
534). Cheltenham, UK: Edward Elgar Publishing. https://doi.org/10.4337/9781788 110426.00039

Kristen, C., Mühlau, P., \& Schacht, D. (2016). Language acquisition of recently arrived immigrants in England, Germany, Ireland, and the Netherlands. Ethnicities, 16(2), 180-212. https://doi.org/10.1177/1468796815616157

Lang, F. R., Weiss, D., Stocker, A., \& von Rosenbladt, B. (2007). Assessing cognitive capacities in computer-assisted survey research: Two ultra-short tests of intellectual ability in the Germany Socio-Economic Panel (SOEP). Schmollers Jahrbuch. Journal of Contextual Economics, 127(1), 183-191.

Martinovic, B., van Tubergen, F., \& Maas, I. (2009). Dynamics of interethnic contact: A panel study of immigrants in the Netherlands. European Sociological Review, 25(3), 303-318. https://doi.org/10.1093/esr/jcno49

Medalia, A., \& Revheim, N. (2002). Dealing with cognitive dysfunction associated with psychiatric disabilities: A handbook for families and friends of individuals with psychiatric disorders. New York State Office of Mental Health. https:// omh.ny.gov/omhweb/cogdys_manual/cogdyshndbk.pdf https://doi.org/10.1037/ e324832004-001

Phinney, J. S., Romero, I., Nava, M., \& Huang, D. (2001). The role of language, parents, and peers in ethnic identity among adolescents in immigrant families. Journal of Youth and Adolescence, 3O(2), 135-153. https://doi.org/10.1023/A:1010389607319

Rubin, D. B. (1987). Multiple imputation for nonresponse in surveys. Wiley: New York. https://doi.org/10.1002/9780470316696

Schacht, D., Kristen, C., \& Tucci, I. (2014). Interethnische Freundschaften in Deutschland [Interethnic friendships in Germany]. Kölner Zeitschrift für Soziologie und Sozialpsychologie, 66(3), 445-458. https://doi.org/10.1007/ s11577-014-0280-7

Schnepf, S. V. (2007). Immigrants' educational disadvantage: An examination across ten countries and three surveys. Journal of Population Economics, 2O(3), 527545. https://doi.org/10.1007/s00148-006-0102-y

Spörlein, C., \& Kristen, C. (2019). Why we should care about regional origins: Educational Selectivity among refugees and labor migrants in Western Europe. Frontiers in Sociology, 4. https://doi.org/10.3389/fsoc.2019.00039

Spörlein, C., Kristen, C. Schmidt, R., \& Welker, J. (2020). Selectivity profiles of recently arrived refugees and labour migrants in Germany. Soziale Welt, 71(1-2), 54-89. https://doi.org/ 10.5771/0038-6073-2020-1-2-54

Statistisches Bundesamt (2019). Anzahl der Ausländer aus Syrien in Deutschland von 2008 bis 2018 [Number of Syrian foreign nationals in Germany from 2008 to 2018]. https://de.statista.com/statistik/daten/studie/463384/umfrage/auslaenderaus-syrien-in-deutschland/.

Stevens, G. (1999). Age at immigration and second language proficiency among foreign-born adults. Language in Society, 28(4), 555-578. https://doi.org/10.1017/ So047404599004030

Trivedi, J. K. (2006). Cognitive deficits in psychiatric disorders: Current status. Indian Journal of Psychiatry, 48(1), 10-20. https://doi.org/10.4103/0019-5545.31613

Van Tubergen, F. (2010). Determinants of second language proficiency among refugees in the Netherlands. Social Forces, 89(2), 515-534. https://doi.org/10.1353/ sof.2010.0092

Van Tubergen, F., \& Kalmijn, M. (2005). Destination language proficiency in crossnational perspective. A study of immigrant groups in nine Western countries. American Journal of Sociology, 110(5), 1412-1457. https://doi.org/10.1086/ 428931 


\section{School adoption in teacher education}

Markus Janssen, Thomas Wiedenhorn

(Eds.)

\section{School adoption in teacher education} Increasing pre-service teachers' responsibility during practice

2021, 102 pages, pb., € 24,90, ISBN 978-3-8309-4263-4

E-Book: Open Access

Increasing pre-service teachers' responsibility during practice
With contributions by

Sonja Bandorski, Johanna Gosch, Kirsten Großmann, Markus Janssen, Andreas Lund, Monika Merket, Elin $B \emptyset$ Morud, Nataliia Pavlova, Olga Surina, Thomas Wiedenhorn

\section{WAXMANN}

School adoption is an ambitious and innovative partnership model in teacher education which offers unique opportunities for in-service and pre-service teachers. At its core, teachers leave their school to be adopted by student teachers for one week. While the teachers engage in a professional development course outside the school, they are fully substituted by student teachers. In this volume, we present different international concepts of school adoption, lessons learned, and first theoretical considerations. With it, we invite teacher educators in schools, universities, and other institutions to engage into a dialogue about the perspectives school adoption offers for teacher education and teacher education research. 